Prepared in cooperation with the City of Carrollton, Kentucky

\title{
Evaluation of the Groundwater-Flow Model for the Ohio River Alluvial Aquifer near Carrollton, Kentucky, Updated to Conditions in September 2010
}

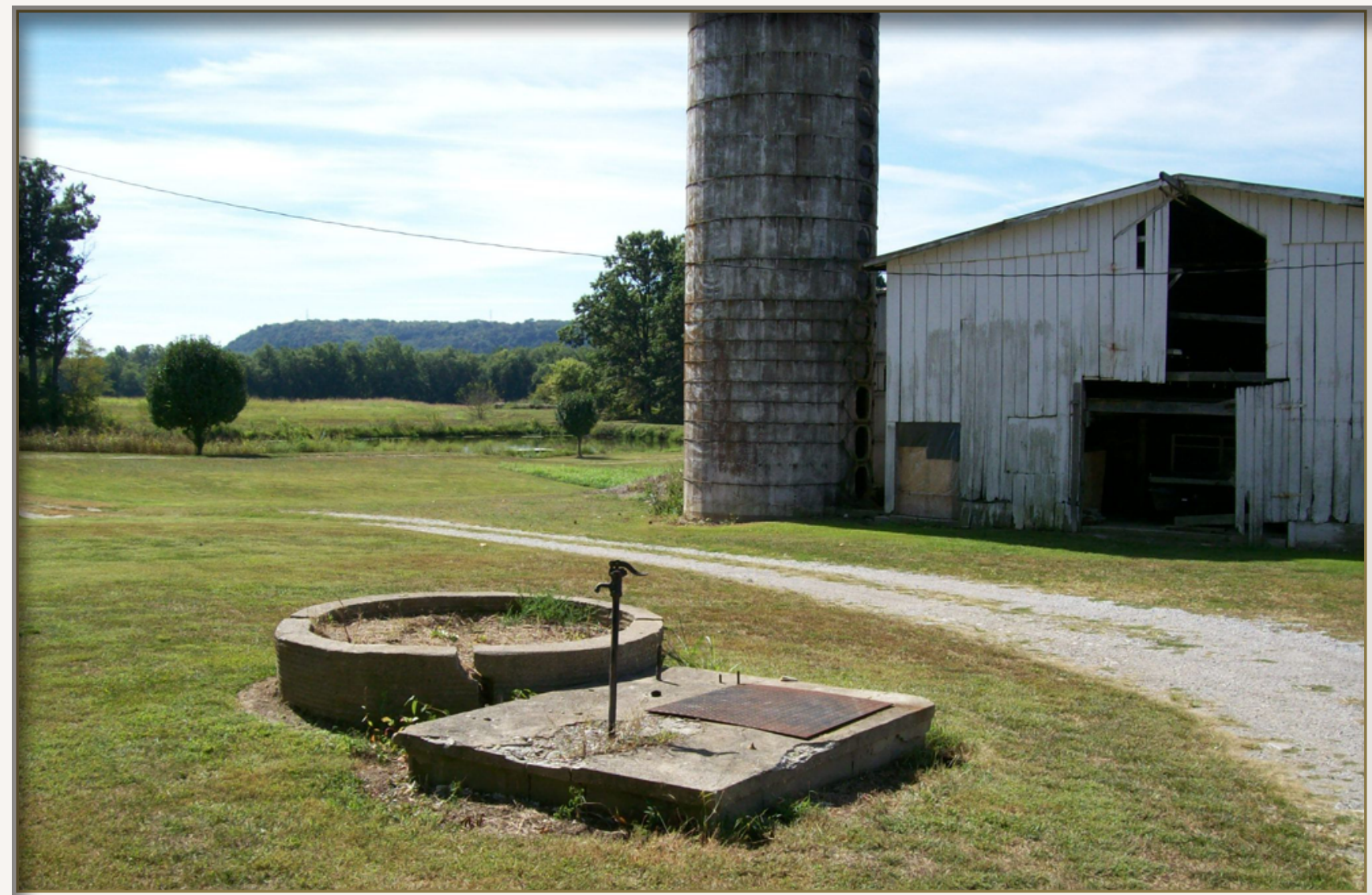

Scientific Investigations Report 2013-5032 
Cover photo. Domestic well used for measuring groundwater levels near Carrollton, Kentucky (Michael D. Unthank, U.S. Geological Survey). 


\section{Evaluation of the Groundwater-Flow Model for the Ohio River Alluvial Aquifer near Carrollton, Kentucky, Updated to Conditions in September 2010}

By Michael D. Unthank

Prepared in cooperation with the City of Carrollton, Kentucky

Scientific Investigations Report 2013-5032 


\section{U.S. Department of the Interior \\ KEN SALAZAR, Secretary}

\section{U.S. Geological Survey \\ Suzette M. Kimball, Acting Director}

U.S. Geological Survey, Reston, Virginia: 2013

For more information on the USGS - the Federal source for science about the Earth, its natural and living resources, natural hazards, and the environment, visit http://www.usgs.gov or call 1-888-ASK-USGS.

For an overview of USGS information products, including maps, imagery, and publications, visit http://www.usgs.gov/pubprod

To order this and other USGS information products, visit http://store.usgs.gov

Any use of trade, firm, or product names is for descriptive purposes only and does not imply endorsement by the U.S. Government.

Although this information product, for the most part, is in the public domain, it also may contain copyrighted materials as noted in the text. Permission to reproduce copyrighted items must be secured from the copyright owner.

Suggested citation:

Unthank, M.D., 2013, Evaluation of the groundwater-flow model for the Ohio River alluvial aquifer near Carrollton, Kentucky, updated to conditions in September 2010: U.S. Geological Survey Scientific Investigations Report 2013-5032, 14 p. 


\section{Contents}

Abstract
Introduction
Purpose and Scope
Description of the Study Area
Description of the Model
Update of the Model to Conditions in September 2010
Performance of the Updated Model
Limitations, Potential Revisions, and New Data to Improve the Updated Model
Summary.
References Cited.

\section{Figures}

1. Map showing location of study area and extent of the Ohio River alluvial aquifer near Carrollton, Ky..

2. Graph showing the Ohio River stage for October 2009 through September 2010 at Markland Dam near Warsaw, Ky., U.S. Geological Survey (USGS) streamflow-gaging station 03277200 ...

3. Map showing the extent of finite-difference model grid near Carrollton, Ky.....................5

4. Map showing locations and amounts of groundwater pumpage near Carrollton, Ky.

5. Map showing observation well network near Carrollton, Ky...........................................

6. Map showing simulated altitude of potentiometric surface of the alluvial aquifer near Carrollton, Ky., September 2010

7. Map showing difference between observed water levels and simulated water levels near Carrollton, Ky.

\section{Tables}

1. Groundwater withdrawals for public water-supply and industrialsupply wells, Carrollton, Ky., September 2010.

2. Observed and simulated water levels and differences for observation wells near Carrollton, Ky.....

3. Volumetric water budget comparison for 1995 model and 2010 model. 10 


\section{Conversion Factors}

Inch/Pound to SI

\begin{tabular}{lcl}
\hline \multicolumn{1}{c}{ Multiply } & By & \multicolumn{1}{c}{ To obtain } \\
\hline inch (in) & Length & \\
inch (in) & 2.54 & centimeter $(\mathrm{cm})$ \\
foot (ft) & 25.4 & millimeter $(\mathrm{mm})$ \\
mile (mi) & 0.3048 & meter $(\mathrm{m})$ \\
\hline & 1.609 & kilometer $(\mathrm{km})$ \\
\hline square mile $\left(\mathrm{mi}^{2}\right)$ & Area & square kilometer $\left(\mathrm{km}^{2}\right)$ \\
\hline & 2.590 & \\
million gallons $(\mathrm{Mgal})$ & Volume & cubic meter $\left(\mathrm{m}^{3}\right)$ \\
cubic foot $\left(\mathrm{ft}^{3}\right)$ & 3,785 & cubic meter $\left(\mathrm{m}^{3}\right)$ \\
\hline & 0.02832 & \\
\hline cubic foot per second $\left(\mathrm{ft}^{3} / \mathrm{s}\right)$ & Flow rate & cubic meter per second $\left(\mathrm{m}^{3} / \mathrm{s}\right)$ \\
cubic foot per day $\left(\mathrm{ft}^{3} / \mathrm{d}\right)$ & 0.02832 & cubic meter per day $\left(\mathrm{m}^{3} / \mathrm{d}\right)$ \\
million gallons per day $(\mathrm{Mgal} / \mathrm{d})$ & 0.02832 & cubic meter per second $\left(\mathrm{m}^{3} / \mathrm{s}\right)$ \\
\hline & 0.04381 & meter per day $(\mathrm{m} / \mathrm{d})$ \\
\hline foot per day (ft/d) & Hydraulic conductivity &
\end{tabular}

SI to Inch/Pound

\begin{tabular}{|c|c|c|}
\hline Multiply & By & To obtain \\
\hline \multicolumn{3}{|c|}{ Length } \\
\hline centimeter $(\mathrm{cm})$ & 0.3937 & inch (in) \\
\hline millimeter $(\mathrm{mm})$ & 0.03937 & inch (in) \\
\hline meter $(\mathrm{m})$ & 3.281 & foot $(\mathrm{ft})$ \\
\hline kilometer $(\mathrm{km})$ & 0.6214 & mile (mi) \\
\hline \multicolumn{3}{|c|}{ Area } \\
\hline square kilometer $\left(\mathrm{km}^{2}\right)$ & 0.3861 & square mile $\left(\mathrm{mi}^{2}\right)$ \\
\hline \multicolumn{3}{|c|}{ Hydraulic conductivity } \\
\hline meter per day $(\mathrm{m} / \mathrm{d})$ & 3.281 & foot per day $(\mathrm{ft} / \mathrm{d})$ \\
\hline
\end{tabular}

Horizontal coordinate information is referenced to the North American Datum of 1983 (NAD 83).

Sea level: In this report, "sea level" refers to the National Geodetic Vertical Datum of 1929 (NGVD of 1929)-a geodetic datum derived from a general adjustment of the first-order level nets of both the United States and Canada, formerly called Sea Level Datum of 1929.

\section{Abbreviations}

$\begin{array}{ll}\text { USGS } & \text { U.S. Geological Survey } \\ \text { RMSE } & \text { Root Mean Square Error }\end{array}$




\title{
Evaluation of the Groundwater-Flow Model for the Ohio River Alluvial Aquifer near Carrollton, Kentucky, Updated to Conditions in September 2010
}

\author{
By Michael D. Unthank
}

\section{Abstract}

The Ohio River alluvial aquifer near Carrollton, Ky., is an important water resource for the cities of Carrollton and Ghent, as well as for several industries in the area. The groundwater of the aquifer is the primary source of drinking water in the region and a highly valued natural resource that attracts various water-dependent industries because of its quantity and quality. This report evaluates the performance of a numerical model of the groundwater-flow system in the Ohio River alluvial aquifer near Carrollton, Ky., published by the U.S. Geological Survey in 1999. The original model simulated conditions in November 1995 and was updated to simulate groundwater conditions estimated for September 2010.

The files from the calibrated steady-state model of November 1995 conditions were imported into MODFLOW-2005 to update the model to conditions in September 2010. The model input files modified as part of this update were the well and recharge files. The design of the updated model and other input files are the same as the original model. The ability of the updated model to match hydrologic conditions for September 2010 was evaluated by comparing water levels measured in wells to those computed by the model. Water-level measurements were available for 48 wells in September 2010. Overall, the updated model underestimated the water levels at 36 of the 48 measured wells. The average difference between measured water levels and model-computed water levels was 3.4 feet and the maximum difference was 10.9 feet. The root-mean-square error of the simulation was 4.45 for all 48 measured water levels.

The updated steady-state model could be improved by introducing more accurate and site-specific estimates of selected field parameters, refined model geometry, and additional numerical methods. Collection of field data to better estimate hydraulic parameters, together with continued review of available data and information from area well operators, could provide the model with revised estimates of conductance values for the riverbed and valley wall, hydraulic conductivities for the model layer, and target water levels for future simulations. Additional model layers, a redesigned model grid, and revised boundary conditions could provide a better framework for more accurate simulations. Additional numerical methods would identify possible parameter estimates and determine parameter sensitivities.

\section{Introduction}

The Ohio River alluvial aquifer near Carrollton, Ky., is an important water resource for the cities of Carrollton and Ghent and several local industries. The aquifer is the primary source of drinking water in the region and a highly valued natural resource that attracts various water-dependent industries because of its quantity and quality. In 1999, the U.S. Geological Survey (USGS), in cooperation with the Carroll County Water-Supply Board, published the results of an investigation to characterize the hydrogeology of the Ohio River alluvial aquifer beneath Carrollton and the surrounding area. That investigation included the development of a groundwater-flow model that has been used to provide local water-resources managers with the information and simulation capabilities necessary to help manage and protect the area's groundwater resources (Unthank, 1999). Since 1995, the groundwater-flow model has been used numerous times to study the possible effects of groundwater withdrawals from proposed new industries to the area and changes in withdrawals from groundwater users. However, an updated model for more recent (2010) conditions is not available to the public.

In 2010, the USGS began a 2-year study of the groundwater resources in the Ohio River alluvial aquifer near Carrollton in cooperation with the City of Carrollton and a coalition of local water utilities and private industries. The principal objective of this study was to update the model to 2010 conditions. Because changes in withdrawals are the most significant changes to the modeled area and they are relatively small and not near the boundaries of the model, the original model should be appropriate to simulate these changes. The original calibrated steady-state model (Unthank, 1999) was updated and evaluated as part of this study to determine how well it simulated the period of steady-state conditions observed in September 2010. 


\section{Purpose and Scope}

This report evaluates the performance of an updated numerical model of the groundwater-flow system in the Ohio River alluvial aquifer near Carrollton, Ky., that originally simulated conditions in November 1995, in simulating groundwater conditions estimated for September 2010. An updated estimate of recharge to the groundwater-flow system from precipitation and revised groundwater discharges from production wells in the area were added to the original groundwater-flow model. The ability of the updated groundwater-flow model to match hydrologic conditions observed in September 2010 was evaluated by comparing measured water levels in a network of observation wells to those computed by the model.

A numerical simulation model of the groundwater-flow system is a quick yet thorough tool that can be used as afor water-use and environmental-planning decisions. As new data and information become available, testing the performance of the model against those data will result in a better understanding of the model and the groundwater-flow system (Konikow and Bredehoeft, 1992). As the demands on groundwater resources of the study area continue to increase, the updated model can help water-resources managers to evaluate the effects on the groundwater-flow system from potential land development and industrial growth and expansion, changes in groundwater withdrawals, and long-term changes in precipitation and other forms of recharge.

\section{Description of the Study Area}

The study area spans parts of Carroll and Gallatin Counties in north central Kentucky (fig. 1). It consists of approximately 20 square miles $\left(\mathrm{mi}^{2}\right)$ of the Ohio River valley extending from the Kentucky River at Carrollton northeast to the Markland Locks and Dam near Warsaw, Ky. The study area is approximately 15 miles (mi) long and ranges in width from about $1.5 \mathrm{mi}$ near Ghent to about $3 \mathrm{mi}$ at Carrollton. The study area is bounded on the northwest by the Ohio River and on the southeast by steep bedrock valley walls. Land surface altitude in the study area ranges from 420 to 490 feet (ft) above sea level in the valley to slightly more than $800 \mathrm{ft}$ above sea level atop the valley walls. Soils in the area are mostly silt and clay. Normal pool stage of the Ohio River and the Kentucky River in the study area is approximately $422 \mathrm{ft}$ above sea level (fig. 2). Most of the area has been cleared for industrial use, but areas of agriculture are interspersed with institutional, recreational, and residential areas.

The population of Carrollton was 3,938 in 2010; Carroll County had a population of 10,811 while Gallatin County had a population of 8,589 (U.S. Census Bureau, 2010). The climate is temperate and the total precipitation from September 2009 through August 2010 was 40.66 inches (in) (National Oceanic and Atmospheric Administration Climate Summary available at $h t t p: / / w w w . w r c c . d r i . e d u / c g i$-bin/ cliMAIN.pl?ky8446). The daily mean discharge of the Ohio
River at Markland Dam (USGS station number 03277200) from September 2009 through August 2010 was 103,300 cubic feet per second ( $\left.\mathrm{ft}^{3} / \mathrm{s}\right)$, (http://waterdata.usgs.gov/ $\mathrm{ky} / \mathrm{nwis} /$ annual/?search_site_no $=03277200 \&$ agency $c d=U S G S \&$ referred_module $=$ sw\&format $=$ sites_selection links).

\section{Groundwater Hydrology}

Under natural conditions, regional groundwater flow in the alluvial aquifer is predominately horizontal, from the alluvium/bedrock boundary at the valley wall towards the Ohio River. This flow pattern is interrupted by cones of depression in the potentiometric surface formed in areas of large groundwater withdrawals. Water-level measurements and lithologic data indicate the alluvial aquifer to be unconfined (Unthank, 1999).

Recharge to the alluvial aquifer is from vertical infiltration of precipitation, flow from the valley wall, and infiltration from the Ohio River and smaller streams. Natural infiltration of water from the Ohio River to the alluvial aquifer may occur during periods of high river stage. Flood pulses originating from the Ohio River can reverse the groundwater gradients, thus recharging water back into the aquifer. Additional recharge to the alluvial aquifer occurs when pumping at groundwater production wells adjacent to the Ohio River and smaller streams lowers the water table below the stage of the streams, thus inducing recharge of surface water to the aquifer.

Discharge from the alluvial aquifer is by flow to the Ohio River and to pumped wells.

\section{Description of the Model}

The USGS developed a numerical flow model in 1998 to simulate the groundwater-flow system of the Ohio River alluvial aquifer near Carrollton, Ky. (Unthank, 1999). The modular, finite-difference computer program MODFLOW (McDonald and Harbaugh, 1988) was used to construct a regional, two-dimensional, steady-state model of the groundwater-flow system in the alluvial aquifer. The model consisted of 1 layer, 36 rows, and 207 columns for a total of 7,452 model grid cells with 5,237 active cells (fig. 3). Model grid-cell sizes varied from $200 \mathrm{ft}$ by $200 \mathrm{ft}$ in areas with wells and groundwater withdrawals to $1,000 \mathrm{ft}$ by $1,500 \mathrm{ft}$ for areas where data were sparse or near model boundaries.

Simulated recharge to the groundwater-flow system included infiltration of precipitation, subsurface flow from consolidated rocks along the valley wall, and seepage from streams. The amount of recharge from precipitation was estimated to be 12 percent of the total precipitation (42.05 in) for the 12-month period of December 1994 through November 1995. Rorabaugh (1956) estimated the recharge to the alluvial aquifer in Louisville to be as much as 12 percent of the annual precipitation; this percentage of the annual precipitation was 


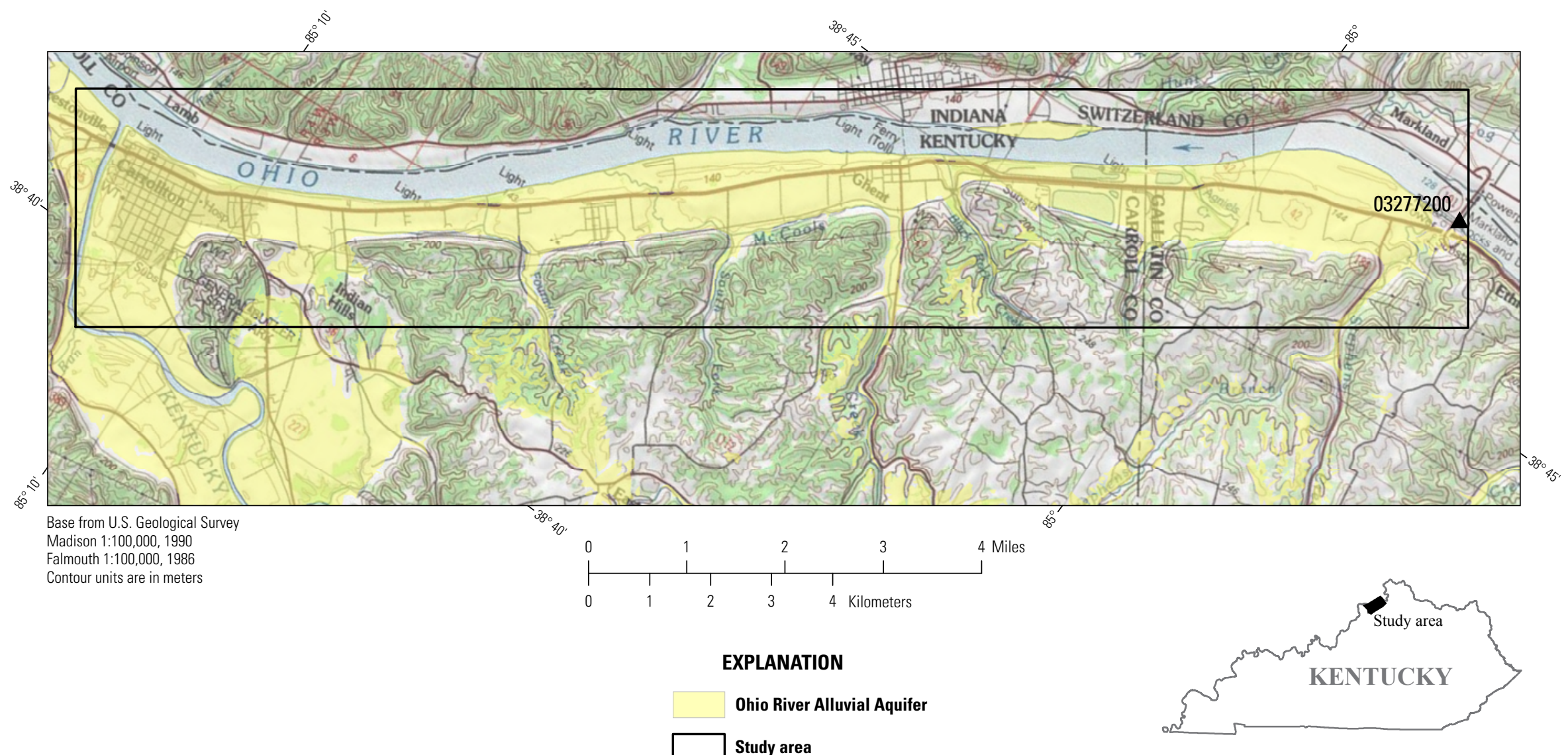

03277200 _ Gaging staton

Figure 1. Location of study area and extent of the Ohio River alluvial aquifer near Carrollton, Ky. 


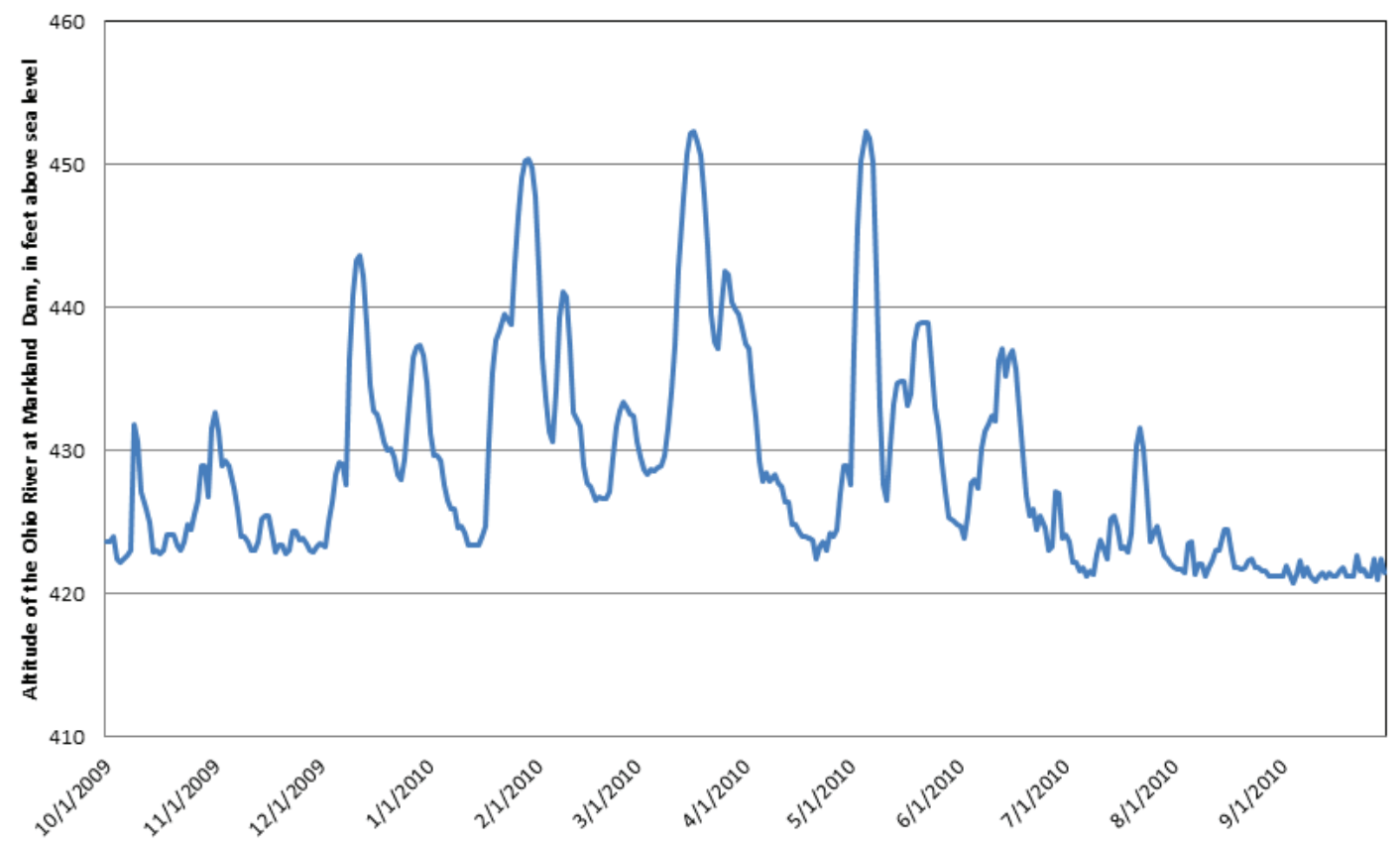

Figure 2. Graph showing the Ohio River stage for October 2009 through September 2010 at Markland Dam near Warsaw, Ky., U.S. Geological Survey (USGS) streamflow-gaging station 03277200.

assumed to be reasonable for the Carrollton area because the study areas are similar. Recharge from precipitation was distributed at a constant daily rate to all active model cells. The contact between the valley-fill alluvial deposits and the bedrock wall along the southeast edge of the study area was modeled as a head-dependent flux boundary with horizontal recharge available to the aquifer. Groundwater recharge from subsurface flow along the valley wall, estimated by the model using a head-dependent flux boundary, was about 27,800 cubic feet per day $\left(\mathrm{ft}^{3} / \mathrm{d}\right)$ per mile of boundary. An external boundary head of $600 \mathrm{ft}$ above sea level was assumed for each cell. The conductance between the external source and the aquifer was estimated at 10 feet per day $(\mathrm{ft} / \mathrm{d})$ and held constant along the entire boundary. Seepage from streams was distributed to model cells representing each stream according to the rate determined for steady-state conditions specified by Unthank (1999). The total amount of recharge to the groundwater-flow system estimated under steady-state conditions of November 1995 was 3,034,800 $\mathrm{ft}^{3} / \mathrm{d}$.

A major hydrologic feature of the groundwater-flow system is the Ohio River. The river is hydraulically connected to the aquifer throughout the study area and can be both a source of recharge and point of discharge for the model. The river was simulated using the River Package in MODFLOW with the stage held at a constant $421 \mathrm{ft}$ above sea level. The riverbed was held constant at $385 \mathrm{ft}$ above sea level. The hydraulic conductivity of the riverbed was held at $0.65 \mathrm{ft} / \mathrm{d}$ based on estimates from Grubb (1975).

Other input parameters used for the simulation, but not varied, included the horizontal hydraulic conductivity of the alluvial deposits and the groundwater withdrawals. The horizontal hydraulic conductivity of the model layer was held at $350 \mathrm{ft} / \mathrm{d}$; groundwater withdrawals were simulated for 29 wells with a total withdrawal of 16.9 million gallons per day (Mgal/d).

The bedrock beneath the alluvial deposits in the study area is comprised of shale and limestone and is not considered a source of water to the overlying alluvial aquifer. As such, the contact between the bedrock and the alluvial aquifer was modeled as a no-flow boundary.

Unthank (1999) compared observed and simulated water levels for 48 observation wells for the November 1995 conditions. The simulated water levels compared closely to the observed water levels for most of the wells. The average absolute difference between the observed and simulated water levels for the 48 wells was $1.43 \mathrm{ft}$; the maximum difference was $4.43 \mathrm{ft}$. The root mean square error (RMSE) of the model simulation was 1.80 . 


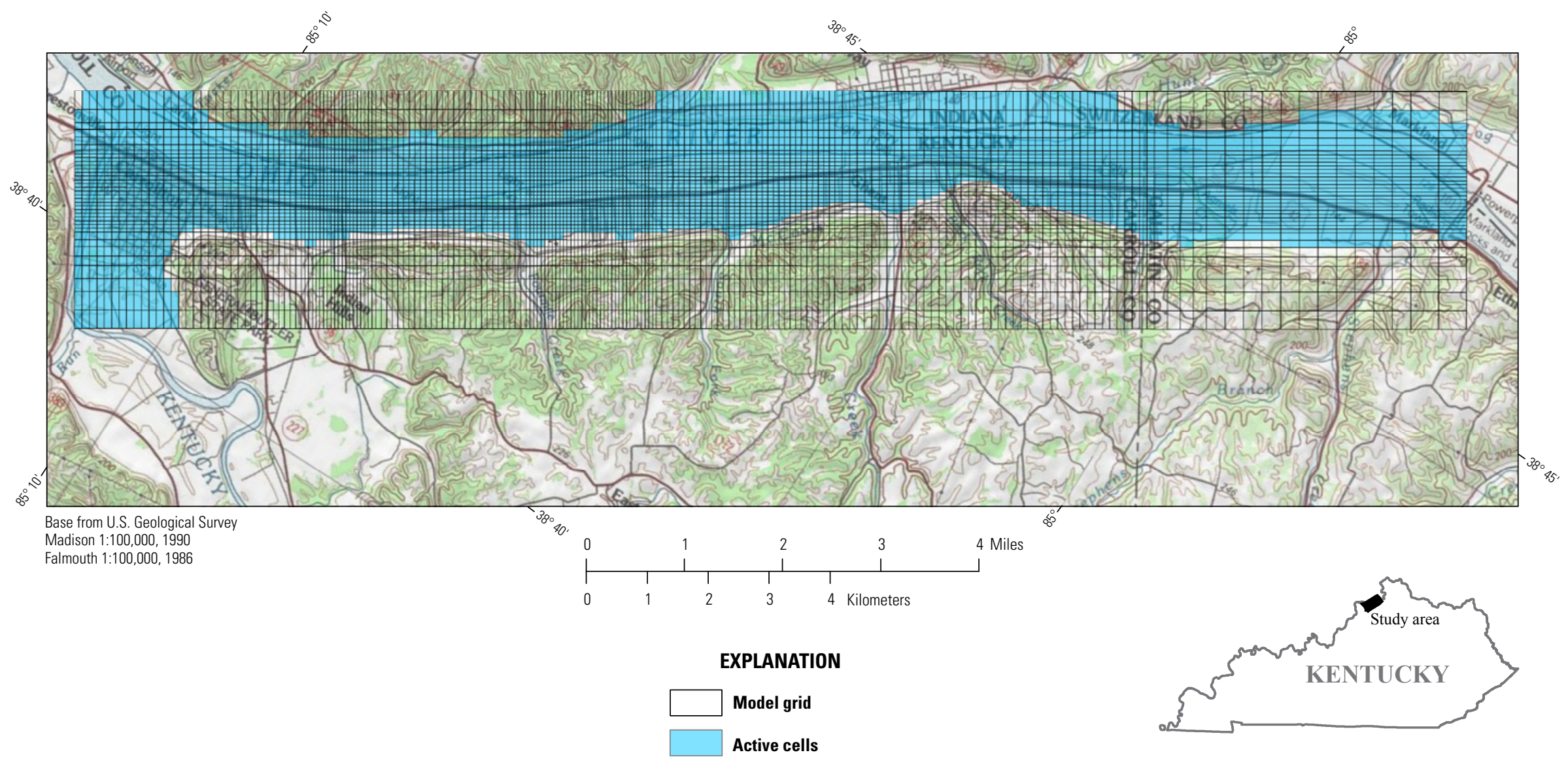

Figure 3. Extent of finite-difference model grid near Carrollton, Ky. 


\section{Update of the Model to Conditions in September 2010}

Data files from the previous steady-state model (Unthank, 1999) were imported into MODFLOW-2005 (Harbaugh, 2005) to update the model to conditions in September 2010. MODFLOW-2005 is an updated version of MODFLOW (McDonald and Harbaugh, 1988). Well and recharge data files were modified as part of this update. The design of the updated model and other input files is the same as the original model.

Discharge from pumping wells in the Carrollton area was estimated on a daily basis from records obtained from local well operators. Collectively, withdrawals from wells in the area during September 2010 were estimated to be about $22.1 \mathrm{Mgal} / \mathrm{d}$. The total number of operating wells was 31 (fig. 4 and table 1). Pumping rates were assigned to model cells representing withdrawal wells; flows were distributed by well and were based on operator records. The total daily discharge from pumping wells in November 1995, used by the original model, was $16.9 \mathrm{Mgal} / \mathrm{d}$ and this value was assigned to 24 wells. Therefore, from 1995 to 2010 , total daily discharge from pumping wells has increased by $5.2 \mathrm{Mgal} / \mathrm{d}$; the number of pumping wells has increased by 7 .

Daily recharge estimates from precipitation for the updated model were calculated as a percentage of the total precipitation for the 12-month period beginning in September 2009 and ending in August 2010. The total precipitation for this period was 40.66 in as measured at the National Oceanic and Atmospheric Administration climate station at Markland Dam (Station 158446). This amount represents a 3.3-percent decrease in the amount of recharge available to the updated model compared to the original model input files.

The groundwater-flow system was conceptualized (Unthank, 1999) as a single-layer, steady-state model and remains so in the updated model. The hydraulic properties of the aquifer and the distribution of recharge were not changed in the updated model. The bedrock beneath the alluvial deposits was still considered a no-flow boundary in

Table 1. Groundwater withdrawals for public water-supply and industrial-supply wells, Carrollton, Ky., September 2010.

[Mgal/d, million gallons per day]

\begin{tabular}{clcc}
\hline $\begin{array}{c}\text { Map } \\
\text { number }\end{array}$ & \multicolumn{1}{c}{$\begin{array}{c}\text { Type of } \\
\text { groundwater user }\end{array}$} & $\begin{array}{c}\text { Number of } \\
\text { wells }\end{array}$ & $\begin{array}{c}\text { Withdrawals } \\
\text { (Mgal/d) }\end{array}$ \\
\hline 1 & Public water supply & 3 & 1.5 \\
2 & Industrial supply & 4 & 2.5 \\
3 & Industrial supply & 15 & 15.7 \\
4 & Industrial supply & 2 & 0.5 \\
5 & Public water supply & 4 & 1.7 \\
6 & Industrial supply & 2 & 0.1 \\
7 & Industrial supply & 1 & 0.1 \\
\hline
\end{tabular}

the updated model. As in the original model, a general-head boundary was used to simulate conditions at the valley wall. The River Package in MODFLOW-2005 was used to simulate the groundwater-flow system's boundary with the Ohio River and the groundwater/surface-water interactions. The altitude of the Ohio River stage was held at a constant $422 \mathrm{ft}$ above sea level based on data from the USGS gaging station 03277200 at Markland Locks and Dam for September 2010 (fig. 2).

\section{Performance of the Updated Model}

The ability of the updated model to simulate hydrologic conditions for September 2010 was evaluated by comparing water levels measured in wells to those estimated by the model. Hydrologic conditions at this time of the year are considered to be at or near steady-state conditions. Waterlevel measurements were available for 48 wells in September (fig. 5). Although many of the 48 wells are the same wells measured for the 1995 investigation, the two well networks are not the same. Table 2 is a comparison of the measured water levels in September 2010 to the simulated water levels.

Overall, the updated model underestimated the water levels at 36 of the 48 measured wells (table 2). The average absolute difference between observed water levels and simulated water levels was $3.4 \mathrm{ft}$, and the maximum difference was $10.9 \mathrm{ft}$. The RMSE of the simulation was 4.45 for all 48 measured water levels. The original model produced an average difference in water levels of $1.43 \mathrm{ft}$, a maximum difference of $4.43 \mathrm{ft}$ and a RMSE of 1.80 .

The total recharge to the groundwater-flow system simulated by the updated model was $3,259,976 \mathrm{ft}^{3}$. Infiltration from precipitation accounted for 18.4 percent of the total recharge; flow from the valley wall was approximately 21.3 percent. Induced flow from the Ohio River and other streams combined for the remaining 60.3 percent of the recharge. Discharge for the groundwater-flow system, by way of withdrawals from groundwater production wells, totaled $2,935,750 \mathrm{ft}^{3}(90$ percent), and flow to the Ohio River and other streams totaled $324,338 \mathrm{ft}^{3}$ (10 percent). Volumetric water budgets from the original and the updated models are listed in table 3.

Figure 6 shows the simulated altitude of the potentiometric surface for the alluvial aquifer estimated by the 2010 model. As with the November 1995 results, cones of depression are present as the result of concentrated groundwater withdrawals in industrialized areas and public water-supply well fields. Outside of these production areas, the potentiometric surface shows a slight slope from the valley wall towards the Ohio River. Simulated water levels around the areas of concentrated groundwater withdrawals show the cones of depression in the potentiometric surface to extend well beneath the Ohio River. Although drawdowns in the potentiometric surface beneath the river are typically indicative of induced infiltration, additional field data are needed to confirm this condition and verify its extent. 


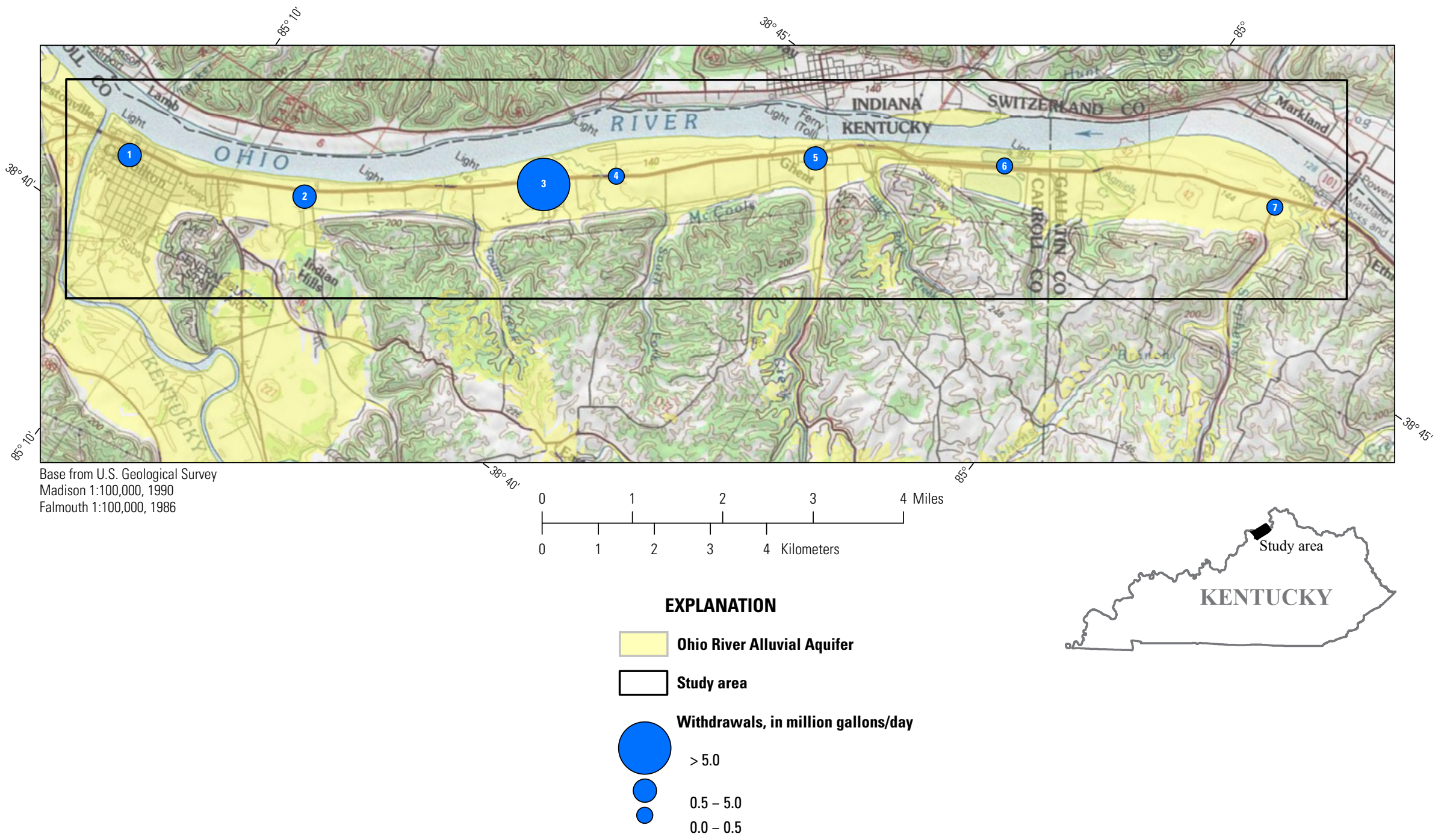

Figure 4. Locations and amounts of groundwater pumpage near Carrollton, Ky. 


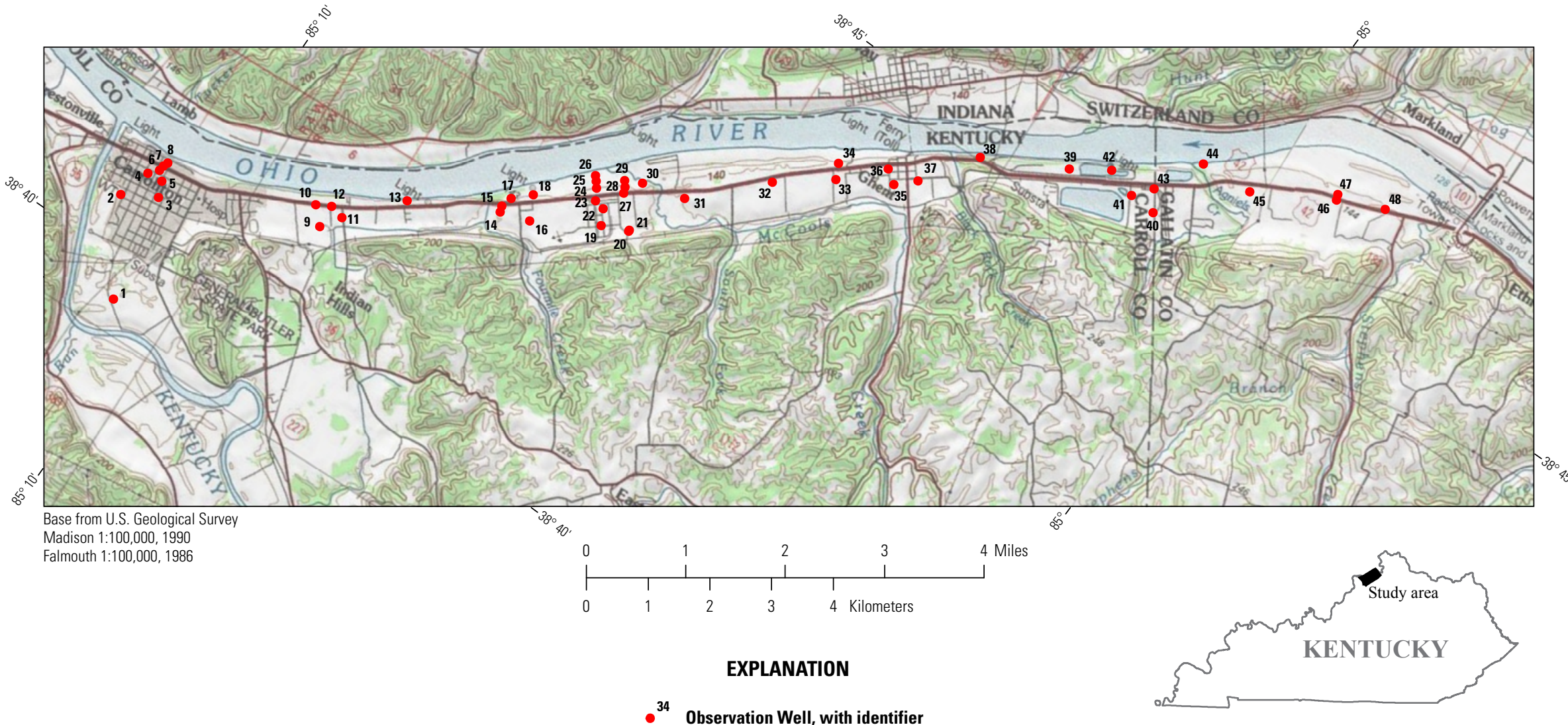

Figure 5. Observation well network near Carrollton, Ky. 
Table 2. Observed and simulated water levels and differences for observation wells near Carrollton, Ky.

[Observation well locations are shown in figure 5. USGS, U.S. Geological Survey; ft, foot]

\begin{tabular}{|c|c|c|c|c|c|}
\hline \multirow{2}{*}{$\begin{array}{l}\text { USGS local well } \\
\text { number }\end{array}$} & \multicolumn{2}{|c|}{ Model cells } & \multirow{2}{*}{$\begin{array}{l}\text { Observed water level } \\
\text { (ft) }\end{array}$} & \multirow{2}{*}{$\begin{array}{c}\text { Simulated water } \\
\text { level (ft) }\end{array}$} & \multirow{2}{*}{$\begin{array}{l}\text { Difference } \\
\text { (ft) }\end{array}$} \\
\hline & Model row & Model column & & & \\
\hline 1 & 35 & 6 & 426.4 & 422.6 & 3.8 \\
\hline 2 & 19 & 7 & 423.6 & 421.3 & 2.3 \\
\hline 3 & 20 & 12 & 423.8 & 420.9 & 2.9 \\
\hline 4 & 14 & 10 & 419.8 & 419.9 & -0.1 \\
\hline 5 & 16 & 12 & 422.4 & 420.1 & 2.3 \\
\hline 6 & 13 & 12 & 421.1 & 419.4 & 1.7 \\
\hline 7 & 12 & 13 & 421.0 & 419.1 & 1.9 \\
\hline 8 & 11 & 13 & 421.3 & 419.6 & 1.7 \\
\hline 9 & 28 & 38 & 418.1 & 418.5 & -0.4 \\
\hline 10 & 22 & 37 & 414.7 & 417.9 & -3.2 \\
\hline 11 & 26 & 44 & 418.3 & 419.3 & -1.0 \\
\hline 12 & 23 & 41 & 417.8 & 417.6 & 0.2 \\
\hline 13 & 21 & 59 & 420.4 & 421.5 & -1.1 \\
\hline 14 & 24 & 75 & 412.6 & 412.8 & -0.2 \\
\hline 15 & 23 & 76 & 414.2 & 411.6 & 2.6 \\
\hline 16 & 27 & 81 & 408.7 & 399.9 & 8.8 \\
\hline 17 & 21 & 77 & 410.6 & 411.3 & -0.7 \\
\hline 18 & 20 & 82 & 415.2 & 407.9 & 7.3 \\
\hline 19 & 28 & 100 & 406.4 & 395.5 & 10.9 \\
\hline 20 & 29 & 107 & 411.1 & 405.4 & 5.7 \\
\hline 21 & 29 & 108 & 411.2 & 406.3 & 4.9 \\
\hline 22 & 23 & 100 & 402.9 & 393.6 & 9.3 \\
\hline 23 & 21 & 98 & 399.3 & 391.8 & 7.5 \\
\hline 24 & 14 & 98 & 410.9 & 407.8 & 3.1 \\
\hline 25 & 16 & 98 & 406.9 & 402.7 & 4.2 \\
\hline 26 & 18 & 98 & 402.9 & 396.4 & 6.5 \\
\hline 27 & 19 & 106 & 404.7 & 394.2 & 10.5 \\
\hline 28 & 18 & 106 & 410.6 & 402.9 & 7.7 \\
\hline 29 & 16 & 106 & 413.2 & 406.8 & 6.4 \\
\hline 30 & 17 & 111 & 410.2 & 411.1 & -0.9 \\
\hline 31 & 21 & 120 & 420.2 & 415.9 & 4.3 \\
\hline 32 & 16 & 135 & 425.1 & 421.5 & 3.6 \\
\hline 33 & 16 & 146 & 426.6 & 422.0 & 4.6 \\
\hline 34 & 11 & 147 & 425.0 & 422.0 & 3.0 \\
\hline 35 & 17 & 155 & 423.9 & 421.2 & 2.7 \\
\hline 36 & 13 & 154 & 422.2 & 420.8 & 1.4 \\
\hline 37 & 16 & 158 & 423.2 & 421.4 & 1.8 \\
\hline 38 & 10 & 166 & 420.7 & 422.4 & -1.7 \\
\hline 39 & 13 & 178 & 422.3 & 422.7 & -0.4 \\
\hline 40 & 24 & 189 & 427.6 & 423.0 & 4.6 \\
\hline 41 & 20 & 186 & 424.3 & 422.9 & 1.4 \\
\hline 42 & 13 & 183 & 422.6 & 422.6 & 0.0 \\
\hline
\end{tabular}


Table 2. Observed and simulated water levels and differences for observation wells near Carrollton, Ky.-Continued [Observation well locations are shown in figure 5. USGS, U.S. Geological Survey; ft, foot]

\begin{tabular}{cccccc}
\hline \multirow{2}{*}{$\begin{array}{c}\text { USGS local well } \\
\text { number }\end{array}$} & \multicolumn{2}{c}{ Model cells } & $\begin{array}{c}\text { Observed water level } \\
\text { (ft) }\end{array}$ & $\begin{array}{c}\text { Simulated water } \\
\text { level (ft) }\end{array}$ & $\begin{array}{c}\text { Difference } \\
\text { (ft) }\end{array}$ \\
\hline 43 & 18 & 189 & 426.9 & 422.7 & 4.2 \\
44 & 11 & 193 & 422.7 & 421.8 & 0.9 \\
45 & 19 & 196 & 425.6 & 425.2 & 0.4 \\
46 & 21 & 201 & 427.5 & 422.9 & 4.6 \\
47 & 19 & 201 & 427.1 & 422.8 & 4.3 \\
48 & 23 & 203 & 421.6 & 422.9 & -1.3 \\
\hline
\end{tabular}

Table 3. Volumetric water budget comparison for 1995 model and 2010 model.

$\underline{\left[\mathrm{ft}^{3}, \text { cubic feet }\right]}$

\begin{tabular}{|c|c|c|}
\hline Model input & 1995 model $\left(\mathrm{ft}^{3}\right)$ & 2010 model $\left(\mathrm{ft}^{3}\right)$ \\
\hline Flow from the Ohio River & 983,900 & $1,753,800$ \\
\hline Flow from the bedrock valley wall & 723,000 & 694,700 \\
\hline Recharge from precipitation and area streams & $1,327,900$ & 811,500 \\
\hline TOTAL & $3,034,800$ & $3,260,000$ \\
\hline \multicolumn{3}{|l|}{ Model output } \\
\hline Discharge to withdrawal wells & $2,511,400$ & $2,935,800$ \\
\hline Discharge to the Ohio River & 520,800 & 324,300 \\
\hline TOTAL & $3,032,200$ & $3,260,100$ \\
\hline
\end{tabular}




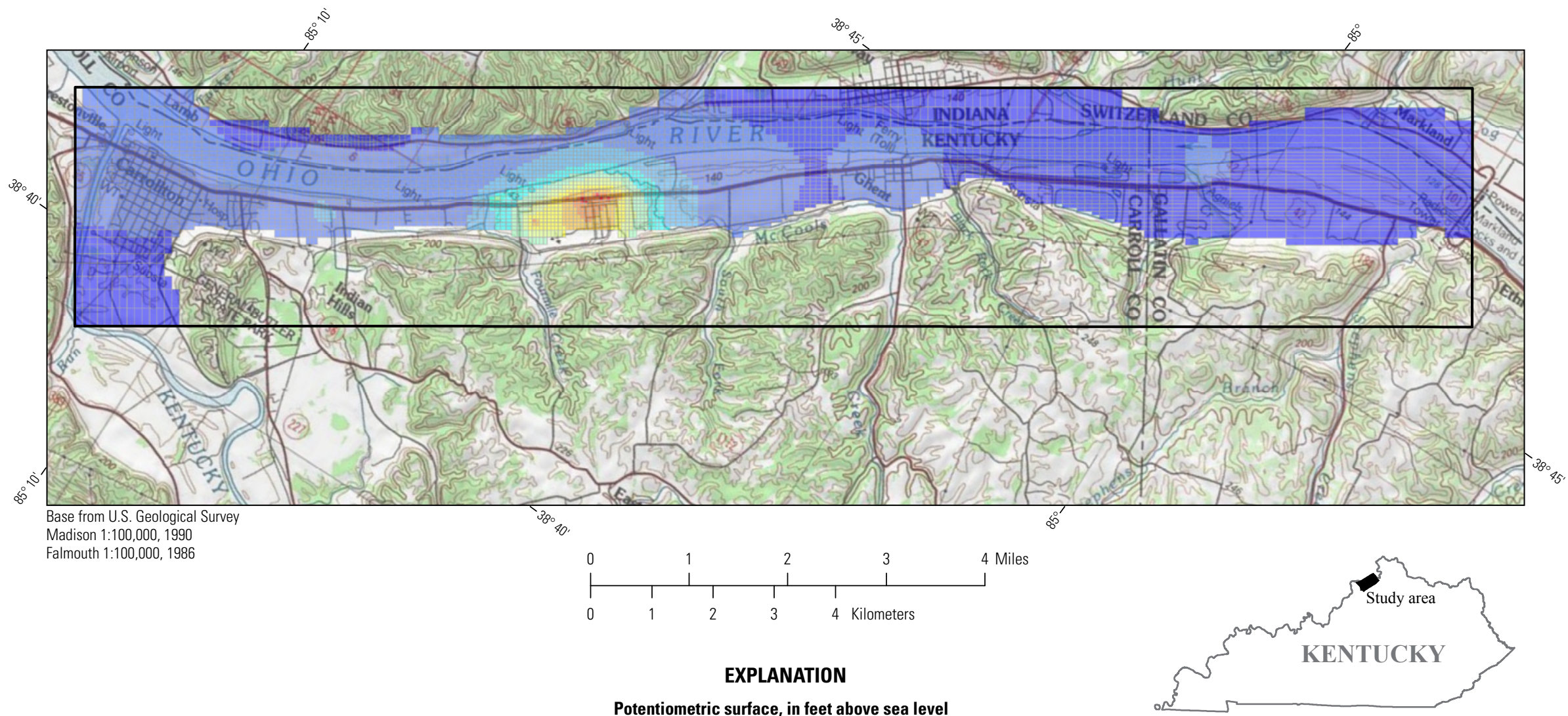

Potentiometric surface, in feet above sea level 
Figure 7 shows the difference between the observed water levels and the simulated water levels for the 48 observation wells, indicated by graduated circles. Overall the observed water levels are higher than the simulated water levels, meaning the updated model is underpredicting the observed potentiometric surface. Water-level differences in 38 of 48 wells are less than $5 \mathrm{ft}$ (table 2 and figure 7), and the greatest differences in water levels are found near the areas of concentrated groundwater withdrawals. Increasing the available recharge by increasing the percentage of precipitation infiltration, allowing more water to flow from the valley wall, assigning higher streambed conductance for the river, or combinations of all three can provide more water to the model. Additional measures, such as adjusting hydraulic conductivity values and resizing the model grid, may help to redistribute water in areas of concentrated groundwater withdrawals and reduce the difference in observed and measured water levels.

\section{Limitations, Potential Revisions, and New Data to Improve the Updated Model}

The limitations of the updated model are much the same as the limitations of the original model (Unthank, 1999). The detail and scale of the original model limits applications of this model as described in Unthank (1999). Relatively large changes in infiltration or pumping (approximately $25 \%$ ) can be simulated with some accuracy, but detailed changes, such as rearranging withdrawals within a well field, may be limited by the scale of the model.

The updated steady-state model of the groundwater-flow system of the Ohio River alluvial aquifer near Carrollton, Ky., could be further improved by making revisions based on data-collection activities designed to better quantify two critical sources of recharge to the flow system- flow from the bedrock valley wall and infiltration from the Ohio River. For the updated model, flow from the bedrock valley wall is configured as a general-head boundary. The quantity of flow across a general-head boundary is governed by water levels outside of the model area (external source) and the hydraulic conductance of the interface between the aquifer cell and the boundary (McDonald and Harbaugh, 1988). Identifying observation wells outside of the model boundary and conducting aquifer tests near the valley wall will provide data on the area's external sources of water and the connectivity of these external sources to the aquifer. Similarly, the quantity of flow available to the aquifer from the induced infiltration of river water is characterized by how easily water moves from the river, through the riverbed, and into the alluvial deposits. Datacollection activities that can help characterize this connection and determine the amount of recharge available from the river include maintaining an observation well network to identify areas of induced infiltration, conducting floodwave analyses to calculate hydraulic conductivities and measuring infiltration rates directly with seepage meters. A series of potentiometric maps of the groundwater can be developed from water-level measurements taken from an observation well network and used to identify changing conditions in the aquifer and possible areas of drawdown in the river. Water-level measurements from temporary piezometers installed in the river can supplement the potentiometric surface mapping and help to delineate drawdowns beneath the river. Recording the aquifer's response to flood events on the Ohio River and analyzing the movement of the floodwave is a direct means of calculating hydraulic conductivities near the river and characterizing the connection between the Ohio River and the aquifer. Lastly, seepage meters can measure the infiltration rates of the river water in areas of drawdown. The data can be used to calculate the vertical hydraulic conductivity of the riverbed. Collectively, these data-collection activities can provide the data and information to assess the amount of available recharge more accurately and determine the rates at which the recharge can be supplied to the model.

Estimating the hydraulic conductivities assigned to the alluvial deposits could also improve the model representation of the groundwater-flow system. A generalized value of $350 \mathrm{ft} / \mathrm{d}$ was used as the hydraulic conductivity for the entire model layer in both the original and the updated model. Hydraulic-conductivity discretization for the model layer could be revised based on data and information available from field activities such as site assessments, installation and testing of new groundwater-production wells, and evaluation of existing production wells.

The accuracy of model simulations could improve by refining the model geometry and utilizing additional numerical methods. Additional model layers, finer model grid discretization, and revised boundary conditions are potential revisions to the model geometry that could improve the model's performance. Likewise, model packages such as UCODE 2005 (Poeter and others, 2005) and PEST (Doherty and Hunt, 2010) could strengthen the model's accuracy by performing sensitivity, calibration, and uncertainty analyses and parameter estimations respectively.

\section{Summary}

The Ohio River alluvial aquifer near Carrollton, Ky., is an important water resource for the cities of Carrollton and Ghent, as well as for several industries in the area. The aquifer is the primary source of drinking water in the region and a highly valued natural resource, attractive to various waterdependent industries because of its quantity and quality. In 1998, the USGS completed an investigation to characterize the hydrogeology of the Ohio River alluvial aquifer beneath Carrollton and the surrounding area and provide local waterresources managers with the information and modeling capabilities necessary to help manage and protect the area's 


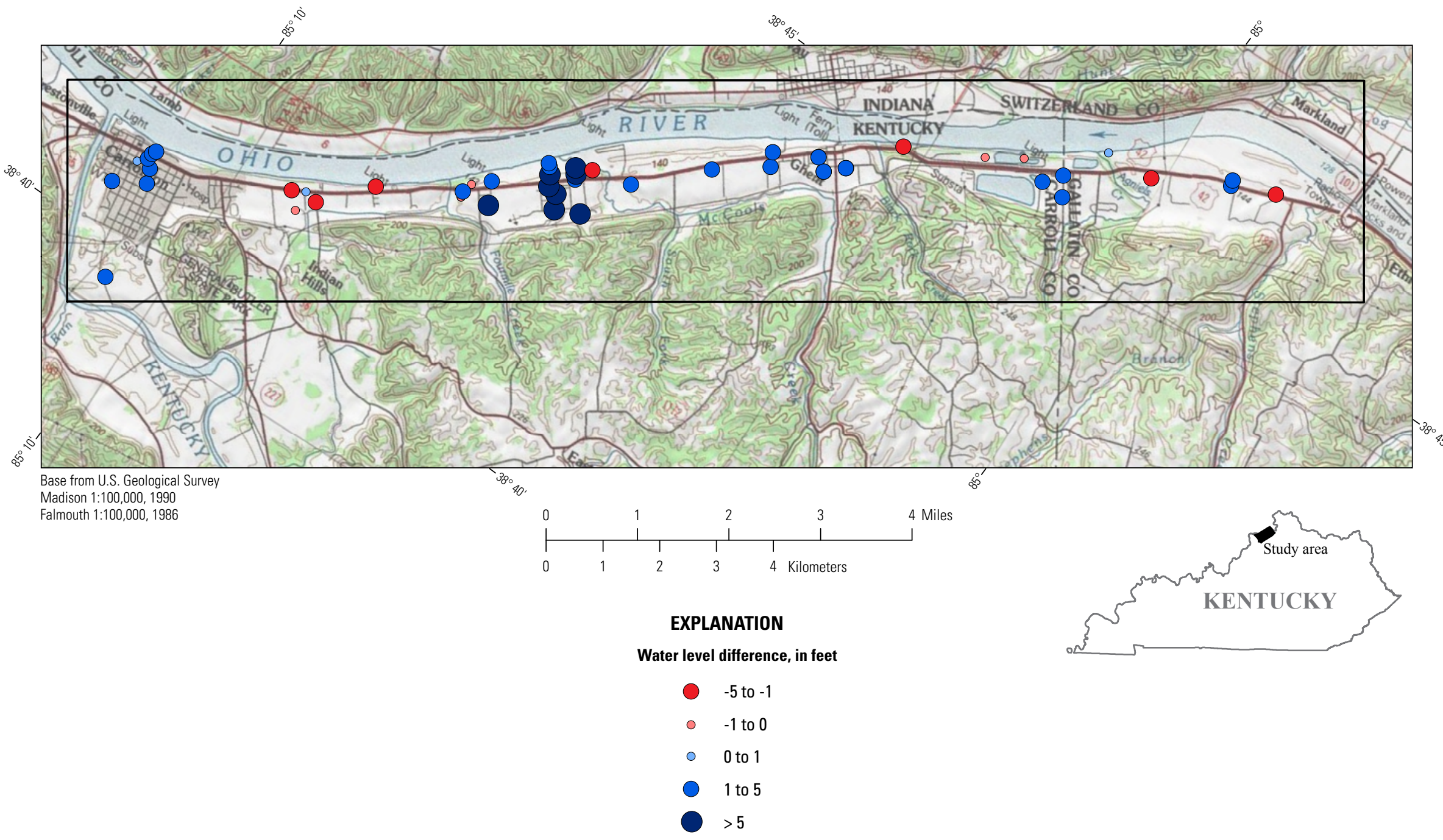

Figure 7. Difference between observed water levels and simulated water levels near Carrollton, Ky. 
groundwater resources. Then in 2010, the USGS, in cooperation with the City of Carrollton and a coalition of local water utilities and private industries, began a 2-year study to update the modeling capabilities from the previous 1998 investigation. The original steady-state model has been updated and evaluated to determine how well it simulated the steadystate conditions of the groundwater-flow system observed in September 2010.

The files from the original steady-state model were imported into MODFLOW-2005 to update the model to conditions in September 2010. The main model input files modified as part of this update were the well and recharge files. Discharge from pumping wells was estimated on a daily basis. For September 2010, a total of $19.9 \mathrm{Mgal} / \mathrm{d}$ was pumped from 31 wells. This represents an increase of $3 \mathrm{Mgal} / \mathrm{d}$ from the November 1995 simulation of $16.9 \mathrm{Mgal} / \mathrm{d}$ discharged from 29 wells. The daily recharge from precipitation was decreased 3.3 percent based on a 12-month total of 40.66 in for 2009 through 2010, compared to 42.05 in for the 1995 simulation. The remainder of the input files and basic model design remained the same as the original model.

The ability of the model to match hydrologic conditions for September 2010 was evaluated by comparing water levels measured in wells to those computed by the model. Water-level measurements were available for 48 wells in September 2010 - a time of the year when the groundwaterflow system is considered to be at or near steady-state conditions with stable stage conditions on the Ohio River and near constant withdrawals from area production wells. Differences in observed water levels compared to modeled water levels ranged from 0 to $10.9 \mathrm{ft}$ with an average of $3.4 \mathrm{ft}$.

The updated steady-state model can be improved with more accurate and site-specific estimates of selected field parameters, refined model geometry, and additional numerical methods. Properly designed data collection activities and continued review of available data and information from area well operators would provide the model with revised estimates of conductance for the riverbed and valley wall, hydraulic conductivities for the aquifer, and model calibration targets for future simulations. Additional model layers, a redesigned model grid, and revised boundary conditions could provide a better framework for more accurate simulations. Additional numerical methods would identify possible parameter estimates and determine parameter sensitivities.

\section{References Cited}

Doherty, J.E., and Hunt, R.J., 2010, Approaches to highly parameterized inversion-A guide to using PEST for groundwater-model calibration: U.S. Geological Survey Scientific Investigations Report 2010-5169, 59 p.

Grubb, H.F., 1975, Simulated drawdown for selected well fields in the Ohio River alluvial aquifer: U.S. Geological Survey Water-Resources Investigations Report 74-2, 38 p.

Harbaugh, A.W., 2005, MODFLOW-2005, The U.S. Geological Survey modular ground-water model - the ground-water flow process: U.S. Geological Survey Techniques and Methods, book 6, ch. A-16, 264 p.

Konikow, L.F., and Bredehoeft, J.D., 1992, Ground-water models cannot be validated: Advances in Water Resources, vol. 15 , no. 1, p. $75-83$.

McDonald, M.G., and Harbaugh, A.W., 1988, A modular three-dimensional finite-difference ground-water flow model: U.S. Geological Survey Techniques of WaterResources Investigations, book 6, ch. A-1, 586 p.

Poeter, E.P., Hill, M.C., Banta, E.R., Mehl, S., and Christensen, S., 2005, UCODE 2005 and six other computer codes for universal sensitivity analysis, calibration, and uncertainty evaluation constructed using JUPITER API: U.S. Geological Survey Techniques and Methods book 6, ch. A-11, 299 p.

Rorabaugh, M.I., 1956, Ground water in northeastern Louisville, Kentucky, with reference to induced infiltration: U.S. Geological Survey Water-Supply Paper 1360-B, 69 p.

Unthank, M.D., 1999, Hydrogeology and simulation of ground-water flow in the Ohio River alluvial aquifer near Carrollton, Kentucky: U.S. Geological Survey WaterResources Investigations Report 98-4215, 48 p.

U.S. Census Bureau, 2010, American FactFinder: accessed August 18, 2011, at http://factfinder2.census.gov/faces/nav/ jsf/pages/index.xhtml. 



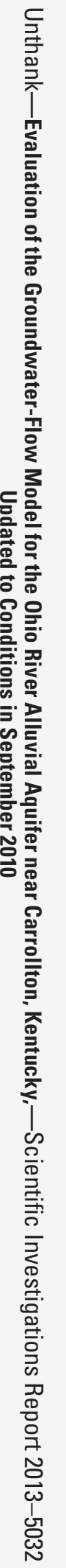

